some of which may be relevant to various lines of research, for example on racial factors in disease.

The binding, and the quality of the paper and printing is very good, particularly, as the publishers point out, for a paper back at its relatively low price.

\section{Fluorescent Protein Tracing}

Edited by R. C. NaIRN, M.D., PH.D. Pp. viii +280 , illustrated. Edinburgh and London: E. \& S. Livingstone. 1962. 425 .

This book is primarily intended for those who are working in the field of fluorescent antibodies. The opening chapters describe in detail the physical and chemical properties of fluorochromes. These substances are conjugated to proteins for study, and the methods for doing this, together with the purification of the conjugates, are given. Physical and chemical properties of the conjugates are described.

The next chapter is devoted to practical details of microscopic equipment required for fluorescent antibody work and information about photomicrography. General considerations on histological methods of study and the various pitfalls encountered, particularly with nonspecific staining, are described in detail.

The latter half of the book makes fascinating reading. Methods for immunological tracing of specific bacteria and other infecting agents, namely, protozoa, helminths, fungi, viruses and rickettsiæ, are discussed, and these are accompanied by extremely good photographs, some of them in colour.

In some virus conditions it has been possible to trace the actual site of production of the antibody within the cell.

However, the author points out that in many conditions in bacteriological and virological work where existing methods are adequate fluorescent microscopy would not be indicated, but where minute amounts of antibody are present it is of undoubted value.

Native tissue antigens have also been studied and it is of considerable interest that malignant tumours lose the ability to show fluorescence with the organ specific antisera. Further exploration into the possibilities of this method of examining tumours is obviously imperative.

This is a very useful book. The author has gone to great trouble to point out the technical snags which are likely to arise. The potentialities of this type of investigation are almost limitless and a book of this kind is of great value to anybody wishing to embark on it.

The bibliography at the end contains 680 references.

\section{The Anatomy of the Cerebro-Spinal Fluid}

J. W. Miller, M.D., D.sC., and D. H. M. WollaM, M.A., M.D., M.R.C.P. Pp. viii + I 51 , illustrated. London: Oxford University Press. I $962.50 s$.

This book is an up-to-date survey of existing knowledge of the cerebrospinal fluid, its formation and circulation. The text is clear and concise throughout and there are many well-chosen diagrams and photographs.

The first chapter is devoted to historical aspects, which, in spite of its necessary brevity, succeeds in being a comprehensive survey from the time of Hippocrates. The anatomy of the ventricular system is outlined and the cavity dimensions presented in tabular form. The author's experience in this field is much in evidence in the chapters on the choroid plexuses and pia mater, which are undoubtedly the highlights of this book. The photomicrographs illustrating the epithelial cells of the choroid plexuses are particularly helpful and later in the book the subdivision of the pia mater into the intima pia and epi-pial tissue is illustrated. It is un- fortunate that a little more space could not be devoted to the cerebrospinal fluid itself, but this is to a large extent compensated for by numerous references in the text.

Postgraduate students, particularly those with an interest in neurology and kindred subjects, will find the book useful and, furthermore, pre-clinical students should benefit from the clear, concise account of the ventricular system and choroid plexuses.

\section{Thalassemia-A Survey of Some Aspects}

ROBIN M. BANNERMAN, M.A., D.M., M.R.C.P. Modern medical monographs. Pp. vi $+\mathbf{r 3 8}^{8}$ illustrated. New York and London: Grune \& Stratton. 196r. 46s.

This manuscript won the first prize in a competition for Modern Medical Monographs, very deservedly, and gives a lucid, concise and yet full account of the information on Thalassemia. As the author rightly points out, these conditions present 'a number of puzzles which are of importance and interest to the general physician, the hæmatologist, the pædiatrician, the biochemist, the geneticist, the epidemiologist, and perhaps even the geographer and historian'. In spite of the wide ramifications of the problem, the author succeeds in giving a full picture.

The book starts with a brief picture of historical background, followed by a chapter on the genetics of the normal hæmoglobins, their distribution and incidence. The third chapter gives the main clinical features with some illustrating case notes, and chapters 4 and 5 the hæmatological findings and points of differential diagnosis. Chapters 6 and 7 deal with the mechanism and processes of hæmoglobin synthesis and various disorderso of hæmoglobin synthesis, with particular reference to ineffective erythropœisis. These chapters lead up to $\leq$ chapter 8, dealing with the iron and hæmoglobin metabolism in Thalassemia. The book is concluded by a stimulating short chapter on the theories of pathogenesis and future possible investigations into the nature of this disease. There are 375 references, with full titles.

The book is eminently readable and highly recommended. It will be only after several readings that the richness of information in the deceptively simple sentences will be appreciated.

\section{Progress in Hamatology Vol. III}

Edited by Leandro M. Tocantins, M.D. Pp ix + 384, illustrated. New York and London: Grune and Stratton. 1962. \$16.50.

This third volume following the previous two, spaced at three-year intervals, gives some indication of the rapid advancements which have been made in hæmatology. There are 14 independent contributions by 25 authors, the majority from the U.S.A. The style of the book follows its predecessors; again the references are not listed uniformly, in some they are in numerical order as in the text and in others in alphabetical order.

With such a work only certain special aspects of hæmatology can be dealt with and there is no attempt at comprehension. Some of the material is academic, e.g. the section on the aetiology of avain leukemia by J. W. Beard.

Hæmatology has been considered in association with other disciplines. The chapter on malignant lymphoma deals chiefly with two methods of differentiation, namely histological and biochemical. The biochemical approach has been well catered for. There are three sections dealing with different aspects of altered plasma 
proteins and an excellent chapter by T. A. J. Prankerd on 'Metabolic Aberration of Erythrocytes'.

Many would appreciate the inclusion of a comprehensive section on radioactive isotopes in hæmatology, although some aspects of their uses are dealt with e.g. by C. G. Craddock 'The Production, Utilization and Destruction of White Blood Cells' and by T. T. Odell and R. M. Kniseley ' The Origin, Life Span, Regulation and Fate of Blood Platelets'.

The hæmoglobinopathies ' have been grudgingly left out' as Tocantins points out in his introduction, and he also writes that the choice of subjects and authors was not an easy task.

\section{Heart Disease-Some Ways to Prevent It}

A. R. Southwood, M.D., M.S., M.R.c.P. Pp. viii + 153, illustrated. William Heinemann Medical Books. 1962. 17s. $6 d$.

This small book is an amplification of the author's Milroy Lectures delivered at the Royal College of Physicians, London, in 1959. Dr. Southwood was formerly Director General of Public Health in South Australia, and his book consists of a survey of the incidence of various cardiovascular diseases (most of the statistics are Australian), followed by a summary of the known xtiological factors in the main groups (congenital, rheumatic, syphilitic, hypertensive and arterio sclerotic) and some hints on their prevention.

These pages bring home to the reader that though the hæmodynamics and pathology of cardiovascular disease have come to be much better understood in the past three decades, there is still surprisingly little we can do to prevent the onset of the most prevalent disorders, hypertension and atherosclerosis. It is well, too, to be reminded what a small fraction ( 1 to $2 \%$ ) of cardiovascular diseases met in practice are contributed by the congenital group, which looms so large in specialist cardiac centres.

The work contains little clinical information that is not familiar to most practising physicians, and will probably be of most value to the student, social worker or layman. It is a readable book which puts its subject nicely in perspective and contains some useful historical and modern references. If preventive measures in some fields of cardiology seem a little meagre, that is hardly the author's fault.

\section{Surgery-Principles and Practice}

H. N. Harkins, M.D., PH.D., C. A. Moyer, M.D., J. E. RhoADS, M.D., D.SC.(MED.) and J. G. AlleN, M.D. Second edition. Pp. xxiv + 1,495, with 652 illustrations. London: Pitman Medical. 1962. £6 6 s.

Second editions are invariably improvements on the first, and this volume is no exception. The layout and general presentation of this large book is excellent, and the text is presented in an easily read style. The diagrams are first class but some of the photographs might be improved in further editions, the detail not always being as clear as it might be. The inclusion of chapters on the history of surgery and military surgery makes refreshing reading, and the latter is especially pertinent in view of the increased interest in traumatic surgery generally. Certain sections (for instance, that on gynæcology) in a textbook of general surgery, may be an innovation for the English reader, and although the authors have set out to make the book as comprehensive as possible, their exclusion might have made it a little less lengthy.

This criticism apart, it is an excellent textbook for the graduate student and also for the postgraduate reading for higher surgical examinations: though one or t望 sections, for instance the complications of certain operations, may not be comprehensive enough for the latter.

\section{The Hremolytic Ansemias, Congenital and} Acquired-Part 2. The Auto Immune Ansemias J. V. DACIE, M.D.(LOND.), HON. M.D.(UPPSALG), F.R.c.P. Second edition. Pp. vi +378 , with fr $_{1}$ illustrations. London: J. and A. Churchepl. 1962. 50s.

This is the second edition of this standard work by one of the leading authorities. Since the first edition ? 1954 the subject has expanded to such an extent that three volumes instead of one are necessary. The first volume was published in 1960 and the final volume $\mathrm{cts}$ promised in two year's time. The present volume deats with the auto-immune hæmolytic anæmias and chapter numbers and headings from the first edition 역e retained, although the reading matter is increased from 164 to 366 pages. This book will require no recofmendation to hæmatologists, to others it will mainly be used as a reference book; both will find it lucid a fd exhaustively informative. Nevertheless there are one or two minor criticisms all concerned with the undoubted disadvantage of the three volumes not being publisherd simultaneously. Unavoidably there are references to the unpublished final volume, and in discussing te association between hæmolytic anæmia and thrombacytopenia Professor Dacie is careful to discuss onty the association with auto-immune hæmolytic anærfila because thrombotic thrombocytopenia is included in the final volume. The index, whilst comprehensive, ois separate for each volume. Perhaps joint authorskip might be an answer to this problem, for all would ofgrete on the undoubted benefit of the three volumes apperisg together.

\section{The Acute Abdomen in Rhyme}

'ZETA'. Fourth edition. Pp. vii + 102, illustratêd by Peter Collingwood. London: H. K. Lev?s. I962. Ios. $6 d$.

' So if you would avoid mistakes, I hardly need $\stackrel{\mathbb{Q}}{0}$ mention,

Routine examination is the method of prevention,

This little book remains a masterpiece, although perhaps not quite the masterpiece that it was 15 years ago. Even emergency surgery has fashions and thete are few surgeons nowadays who would approve of a $\mathrm{r}$-in. abdominal incision under local anæsthesia in orfer to differentiate between pleuritic pain and appendicitis! Nor could typhoid any longer be regarded as one of the common alternatives to acute appendicitis. The ' callö cocky youth', however, ' who from his books has leaont much doubtful truth', still misses perforated pep ic ulcers by scorning the opinion of the "old and ignorant G.P.' Few textbooks have ever been written whieh have surpassed ' Zeta's ' description of acute intestipal obstruction, especially that deadly and insidious tye due to a high jejunal lesion. This book can still be read by old and young alike for instruction and not only tor amusement.

\section{Recent Advances in Pharmacology}

J. M. RoBson, M.D., D.SC., F.R.S.E., and R. StaCeY, M.A., M.D. Third edition. Pp. $\mathbf{x}+406$, with 68 illustrations. London: J. \& A. Churchl. 1962. 545 .

Apart from Professor Stacey replacing Professor Keele as co-editor, this new edition of "Recent Advanछes 